\title{
Chronological reflection on monitoring urban areas subsidence due to groundwater extraction
}

\author{
Alina Radutu ${ }^{1,2^{*}}$ and Radu Constantin Gogu ${ }^{1}$ \\ ${ }^{1}$ Technical University of Civil Engineering Bucharest, Groundwater Engineering Research Centre, Str. Rascoalei 1907 nr. 5, \\ Bucharest, Sector 2, Romania \\ ${ }^{2}$ Romanian Space Agency, 21-25 Mendeleev Str., 010362, Bucharest, Romania
}

\begin{abstract}
Land subsidence affects urban areas worldwide. Sometimes it could be driven by intensive groundwater withdrawal to assure different urban needs and functionalities. Some of these urban areas have a long history of subsidence that covers almost a century. The aim of this paper is to present the evolution of several urban areas affected by land subsidence, the methods used to monitor vertical displacements along the decades in relationship to the groundwater extraction associated to the urban expansion, and the mitigation techniques used for countering the effects of intensive groundwater withdrawal. Even the originally applied subsidence monitoring methods (such as geometric levelling) are still very sensitive, in terms of time consuming, covered area, and financial effort, these methods might be complemented by new methods based on Synthetic Aperture Radar Interferometry (InSAR). InSAR methods show also a significant progress during the last decades when considering the subsidence sensed order of magnitude.
\end{abstract}

\section{Introduction}

Land subsidence represents a degradation form generated by natural or anthropogenic causes, characterized by sinking or settling of the land surface [1] which can affect either local or large areas [2]. One of the anthropogenic land subsidence sources in the urban areas is the intensive groundwater withdrawal to assure different urban needs and functionalities, by causing the compaction of the liable aquifer systems [3]. This comes in the context of rapid population growth and industrial development [4]. Hence, the pumped groundwater is used for industrial purposes, for agricultural and green areas irrigations, for water supply, and for underground infrastructures maintenance. As usually this land surface degradation occurs at a slow rate, the problem is not too often caught in the field until a visible effect arise [5]. However, [3] underlines that land subsidence can also occur as a sudden sinking of different ground sections. The effects can affect manmade infrastructures (roads, railways, bridges, pipelines, buildings) or natural systems (wetlands, surface drainage, river courses, and erosion) [2],[5].

The subsidence phenomena associated to groundwater pumping were recognized at the beginning of the previous century in the U.S.A. [2]. Among the earliest areas that faced subsidence starting before 1920 are: Tokyo (Japan), Mexico City (Mexico), Alabama (U.S.A.), and Santa Clara Valley (U.S.A.) [4],[6].

Unless different methods and techniques for land subsidence monitoring and mitigation solutions revealed

\footnotetext{
* Corresponding author: alina.radutu@rosa.ro
}

over time, this phenomena is still present-day, bringing new techniques and discussions in the spotlight.

\section{Subsidence monitoring methods}

Several methods were used over time for monitoring land subsidence worldwide, such as precise leveling, extensometry, GNSS measurements, and InSAR [7]. These methods can be replenish for better understanding of the phenomena with other methods related to the groundwater, such as piezometric measurements, geotechnical studies, hydrogeologic studies, seismic measurements, geology and stratigraphic data, LIDAR data, absolute gravity, meteorological data, and other relevant methods [8],[9],[10],[11], [12], [13], [14].

\subsection{Precise levelling}

The most precise method of measuring elevation changes at land surface is the precise levelling [15]. This consists in determining the elevation of a bench mark network at land surface. By repeated surveys of the network at different time intervals, it can be revealed whether vertical movements appeared compared to the control bench marks [4]. The control bench marks are placed in stable areas consisting of consolidated rocks, outside the area affected by displacements. The levelling accuracy depends on the equipment and methods used [15]. Hence, according to [4], the most precise leveling method is the leveling of the first order. The first order class I leveling is double run and requires a maximum difference between duplicate lines of $3 \mathrm{k}^{1 / 2} \mathrm{~mm}$, where $\mathrm{k}$ 
is the length of the bench mark line in kilometres [4]. The second levelling class I levelling requires a closing less than $6 \mathrm{k}^{1 / 2} \mathrm{~mm}$ [3], and half of the amount necessary for the first class levelling [4]. Considering the current levelling methods, the standard kilometre error for the precise levelling is less than $1 \mathrm{~mm} /\left(\mathrm{km}^{1 / 2}\right)$ [15],[7].

This subsidence monitoring method is still very used in areas where bench mark networks and historical data are available [3] and for calibrating other kind of measurements.

One of the first monitored bench marks were placed in San Jose, U.S.A., established in 1912 [4]. In Niigata, the Japan Geographical Survey Institute performed firstorder level surveying in several years from 1898, but the subsidence became visible by 1955 [16].

\subsection{Borehole extensometry}

Vertical borehole extensometers are used to measure the movement or change of the vertical distance between the bottom of the borehole and the ground surface, considering the thickness of sediments or rocks [4],[3], [17]. There are several types of extensometers designed over time. Hence, first extensometers were mentioned to be developed in Japan, in the 1930s [4], [17]. These instruments are named single and double pipe extensometers. The amount of compaction occurred in the soft clays are recorded by increased protrusion of the pipe at ground level. Because of the increased frictional resistance along with the depth, the single pipe well cannot be used at depths greater than 50 to $100 \mathrm{~m} \mathrm{[4],}$ hence the double pipe well were designed. The double pipe well lies in a system of two concentric pipes, only the outer pipes having contact with the sediments and coming under the lateral presure. Hereby, the inner pipe can indicate the accurate amount of compaction in the measuring point [4].

The Mexican and U.S. types of extensometers are also mentioned in the scientific literature [4],[3],[17]. The anchored-cable and pipe extensometers were used successfully for different subsidence investigations by U.S.G.S. The first U.S. extensometer used a tensioned cable for measuring the distance variances between the land surface and the bottom-hole anchor fixed near the base of the pumped aquifer system [17]. After different improvements, the equipment could record variations in the thickness of an aquifer system in the order of 0.1 to $0.2 \mathrm{~mm}$ [4]. The free-pipe extensometer, uses similar principles as the Japanese double pipe extensometer [3],[4]. Different problems related to the compressional forces were registered in some investigated areas, emphasizing also the limitations of this measuring method in certain conditions [4].

\subsection{Global Navigation Satellite Systems (GNSS) measurements}

Since 1980s when U.S. Global Positioning System (GPS), the first GNSS constellation, figured out, a new horizontal and vertical displacement measurement technique is available. GNSS techniques lie in the use of at least four navigation satellites for determining absolute $(\mathrm{X}, \mathrm{Y}, \mathrm{Z})$ coordinates at ground surface with respect to a global well-defined geocentric reference system [18]. Considering reference points at ground surface, GNSS networks can be developed in order to survey multiple times various areas of interest. Permanent stations having known $(\mathrm{X}, \mathrm{Y}, \mathrm{Z})$ coordinates can be used for Differential GNSS measurements which allow computing the $3 \mathrm{D}$ position of a roving receiver [3]. By using current measurement technologies and adjustments, GNSS permanent stations are capable of providing vertical velocity measurements of about 1 $\mathrm{mm} /$ year, after more than 3 years of continuous acquisition [7].

Currently, GNSS techniques are used not only for revealing land subsidence, but also for validating other subsidence measuring methods, such as those based on Synthetic Aperture Radar (SAR) [19],[18].

\subsection{Synthetic Aperture Radar Interferometry techniques}

(SAR)

\subsubsection{InSAR technique}

Interferometric SAR (InSAR), is a measuring technique which became popular in the 1990s [20]. The data acquisition is made by coherent active sensors which have day and night operational capabilities, regardless the weather conditions [21]. SAR interferometry is exploting the phase difference of two acquisitions made on the same area at different time moments, from almost the same look angle, generating an interferogram [22],[20]. The distance between the acquisition orbits is a known distance named baseline [20]. The phase interferogram includes different components such as: topographic information, displacement information, atmospheric effect, orbital error information, and noise [23],[21]. By multiple processing steps the interferogram phase can be used for generating a digital elevation model (DEM) of the observed area [23].

Generally, the presence of the topographic distortion and atmospheric effects in the interferometric phase does not permit the estimation of surface deformation [21]. Other restraints of InSAR are related to the decorrelation of the vegetated areas, the interferogram incoherence due to the large baseline between two acquisitions, and the temporal decorrelation [22],[21]. However, an example of good interferometric pair whith good coherence which could be used for estimating land subsidence is given by [3]. The resolution of ground displacement was in the range $+/-10 \mathrm{~mm}$.

\subsubsection{DInSAR technique}

If multiple SAR scenes acquired with the same geometry are available for a studied area, the effects of the topographic component can be removed and the terrain motion component can be measured. This is also available if an external DEM is used for subtracting the topographic component from the interferometric phase [21]. This technique represents the Differential SAR 
Interferometry (DInSAR). One of the limitations of this technique is related to the still present part of the atmospheric effect in the final result [24].

As SAR techniques developed from the InSAR to DInSAR, multiple study cases related to the monitoring of land subsidence were carried on by using DInSAR [25],[26],[27].

\subsubsection{Multi-temporal techniques}

The evolution of SAR techniques gets to multi-temporal InSAR (MTI) techniques which contrived on minimising the atmospheric effect and the loss of coherence by processing long temporal series of SAR data [24]. The accuracy of MTI is less than a few milimetres [20]. The two primary categories of MTI are:

- the Persistent Scatterers Interferometry (PSI) [28] and other similar approaches; PSI consists mainly in the identification and usage of stable natural reflectors, characterized by reliable amplitude and coherent signal phase over all SAR scenes [28],[24]. These are the permanent or persistent scatterers (PSs) revealing the displacements in the time series studied area, relatively to a reference point [21].

- the Small Baseline Subset (SBAS) and related methods; SBAS methods are focusing on pairs of interferograms characterized by small spatial baselines [29] for using more spatially dispensed information [24]. The SBAS concentrates on distributed scatterer, as they are more sensible to temporal and volume decorrelation than PSs [24].

\section{Historical subsiding urban areas due to groundwater pumping}

\subsection{Mexico City}

Mexico City represents one of the oldest urban areas affected by land subsidence due to ground water pumping, dated the end of nineteenth century [4].

The three main geotechnical units of the city are: (a) the hard rock unit (volcanic); (b) the transitional unit; and (c) the lacustrine unit [30],[31].

The first mentioned method for vertical land surface measurements in Mexico City is the precise leveling, which was performed in 1877 and in 1924 [4]. Since then, new precise leveling campaigns (more than 3700 benchmarks available nowadays) and other methods for monitoring land subsidence were used [32]. We can mention: piezometric stations installation, extensometers [4], InSAR, GPS analysis [31], gravimetric data [9], MTI [30] and LiDAR [32].

In 1995, Mexico City metropolitan area consumed over $65 \mathrm{~m}^{3} / \mathrm{s}$ of water, groundwater representing the main source $(70 \%)$, the water table decreasing with values up to $1.5 \mathrm{~m} / \mathrm{yr}$ [31]. Nowadays, because of the demographic development, groundwater is still the main source, water being pumped from deep wells. As mitigation method, exploiting external water sources were proposed [32].
Table 1 presents subsidence values for different areas and distinct time periods.

Table 1. Subsidence values in Mexico City (modified after [4] and [32])

\begin{tabular}{|c|c|c|c|}
\hline Area & $\begin{array}{c}\text { Time } \\
\text { period }\end{array}$ & $\begin{array}{c}\text { Surface } \\
\mathbf{( k m}^{\mathbf{2}} \mathbf{)}\end{array}$ & $\begin{array}{c}\text { Subsidence } \\
\text { values }\end{array}$ \\
\hline $\begin{array}{c}\text { Old City (in } \\
\text { 1973) }\end{array}$ & $1891-1973$ & 27 & 4 to $8.70 \mathrm{~m}$ \\
\hline $\begin{array}{c}\text { Whole City } \\
\text { (in 1973) }\end{array}$ & $1952-1973$ & 145 & 1 to $3.25 \mathrm{~m}$ \\
\hline $\begin{array}{c}\text { Alameda } \\
\text { Central Park }\end{array}$ & $1898-2008$ & 0.2 & $11 \mathrm{~m}$ \\
\hline $\begin{array}{c}\text { Lacustrine } \\
\text { area }\end{array}$ & $1999-2008$ & 1000 & $\begin{array}{c}3 \text { to } 43 \\
\mathrm{~cm} / \text { year }\end{array}$ \\
\hline
\end{tabular}

\subsection{Tokyo, Japan}

Tokyo is an example of urban area where subsidence and groundwater pumping were drastically reduced in the last forty years.

The topography of Tokyo consists of a plain area in the eastern part and a hilly and mountainous area in the western part. The environmental deposition comprises alluvial and shallow marine layers, with a highly permeable redsoil as surface deposit [4],[33].

First signs of subsidence appeared in Tokyo in 1910, because of the high volume of groundwater used in factories. This phenomena intesified in the next decades, until 1970s [33]. By 1965, the head in the confined aquifers from the eastern part of Tokyo declined to as much as $60 \mathrm{~m}$ bellow sea level, considering an initial hydraulic head was above sea level [35]. In the same area, $80 \mathrm{~km}^{2}$ of land subsided below sea level [35]. When considering the groundwater pumpage, at the beginning of $1970 \mathrm{~s}$, the total volume for Tokyo was on the order of $1500000 \mathrm{~m}^{3} /$ day. The maximum cumulative subsidence from 1918 to 1975 was of $4.59 \mathrm{~m}$ [4].

In the 1970s, Tokyo Metropolitan Government (TMG) started different projects for mitigating subsidence effects [33], consisting in: (a) building reservoirs and canals to import surface water; (b) reduction of groundwater withdrawal for industrial and non-drinking purposes; (c) use of environmental plans for rainwater infiltration facility and for waste water for buildings [4],[33],[34]. In 2003, after all mitigation plans were followed out, the hydraulic head rised to 6-10 metres below ground surface, and only a few sites still confronted subsidence rates higher than $1 \mathrm{~cm} / \mathrm{yr}$ [33]. In 2015 the mean subsidence rate in Tokyo was almost zero [36]. The volume of pumped groundwater decreased to $550000 \mathrm{~m}^{3} /$ day in the $2000 \mathrm{~s}$.

The main measurement techniques used for monitoring groundwater withdrawal and land subsidence were: precise leveling, extensometer measurements, piezometric measurements, and InSAR [4],[36],[37].

\subsection{Houston-Galveston area, U.S.A}

The Houston-Galveston area has been affected by land subsidence from the 1943, on an area of approximately $12000 \mathrm{~km}^{2}$ [4]. This was the consequence of 
groundwater withdrawal which began in 1836, and exceeded in $19751.700 .000 \mathrm{~m}^{3} /$ day [38]. In the SE Harris County, from 1917 to 1979, the subsidence rate reached $3 \mathrm{~m}$, and in 2001 it was $4 \mathrm{~m}$ [39].

The area is characterized by a complex geologic setting with fluviatile and shallow marine depositional environment, laterally diverse subsurface hydrological units [4]. For monitoring the groundwater withdrawal and the land subsidence, USGS installed in 1977 an extensive groundwater well network, and since 1990s first-order leveling surveys combined with GPS surveys were conducted periodically [39],[38]. These were combined with extensometer measurements, LIDAR surveys, and in the last decades with InSAR technology measurements. More studies using InSAR, PSI, or SBAS were conducted for covering different time intervals after 1990s [40],[39]. It could be identified areas with subsidence values between 20 and $50 \mathrm{~mm} / \mathrm{yr}$ [40].

\subsection{Bucharest, Romania}

Groundwater exploitation of Bucharest city, during the last stages of industrialisation (1970s and 1980s), affected different areas by land subsidence. For 1981 a flow rate of $1593 \mathrm{l} / \mathrm{s}$ has been estimated. A reduction of the use of groundwater in Bucharest followed, decreasing to $600 \mathrm{l} / \mathrm{s}$ in 2012 [41]. On a site with known recent subsidence, the used monitoring methods started with PSI and were completed in several studies by SBAS, and validated by precise leveling and GNSS measurements [42],[43],[44]. After this period of time, different patterns were registered at land surface, including continuation of subsidence, stabilization or uplift [43], [44]. Starting from 1992, until nowadays [42],[43],[44], for some specific sites were registered maximum subsidence rates of about $15 \mathrm{~mm} / \mathrm{yr}$.

\section{Discussions}

During the previous century, a general trend for the evolution of groundwater extraction, land subsidence and the monitoring methods in urban areas, can be drawn. Hence, the second industrial revolution (18701914) represents the first stage of intensive groundwater pumping and the appearance of land subsidence, and of the use of precise leveling [4]. The peak of groundwater overexploitation occurred at the end of the post war economic boom, at the beginning of 1970s [34]. Meanwhile, the extensometers have been developped [17]. The industrial growth conducted also to the population increase in urban areas and to the corresponding expansion of the water supplies needs. Despite the end of the industrialisation era the groundwater overexploitation and the land subsidence in some urban areas continued until today [32]. This third stage brought the use of GNSS monitoring and of the InSAR techniques.

When looking where the measuring instrument is placed, the land subsidence monitoring methods, can be classified also from this point of view. Therefore, precise leveling and extensometry are methods using in-situ instruments, developed before the space technologies era. GNSS measurements and InSAR techniques are space technologies, the measuring instruments being placed on-board satellites.

Each monitoring method presents advantages and disadvantages, when considering more criteria, such as: accuracy, financial effort, covered area, temporal aspects, and human resources (see Table 2) [7].

Table 2. Comparison of subsidence monitoring methods (modified after [15])

\begin{tabular}{|c|c|c|c|c|}
\hline Method & $\begin{array}{l}\text { Accu- } \\
\text { racy }\end{array}$ & $\begin{array}{c}\text { Covered } \\
\text { area }\end{array}$ & $\begin{array}{c}\text { Temporal } \\
\text { aspects }\end{array}$ & $\begin{array}{c}\text { Human } \\
\text { resources }\end{array}$ \\
\hline $\begin{array}{c}\text { Precise } \\
\text { levelling }\end{array}$ & $<\mathrm{mm}$ & \multirow{3}{*}{ Punctual } & \multirow{3}{*}{$\begin{array}{l}\text { Monthly/ } \\
\text { yearly } \\
\text { campaigns }\end{array}$} & $\begin{array}{c}3-4 \\
\text { (survey) }\end{array}$ \\
\hline $\begin{array}{c}\text { Extensom } \\
\text { eter }\end{array}$ & $<\mathrm{mm}$ & & & $2-3$ \\
\hline GNSS & $\mathrm{mm}$ & & & \\
\hline InSAR & $\mathrm{cm}$ & \multirow{3}{*}{$>100 \mathrm{~km}^{2}$} & \multirow{3}{*}{$\begin{array}{c}\text { Data } \\
\text { available } \\
\text { every 6-46 } \\
\text { days }\end{array}$} & \multirow{3}{*}{$\begin{array}{c}1 \\
\text { (processin } \\
\mathrm{g})\end{array}$} \\
\hline DInSAR & $<\mathrm{cm}$ & & & \\
\hline MTI & $\mathrm{mm}$ & & & \\
\hline
\end{tabular}

When talking about accuracy, unless the oldest method, precise levelling is still the most accurate subsidence monitoring method. For the InSAR methods, an accuracy evolution can be observed considering the centimetre level for InSAR to millimetre level for MTI. On the other side, the first three methods are reaching punctual measurements, implying more human and time resources in comparison with the InSAR methods which could cover very large areas with human involvement only for data processing. Considering the new developed European radar satellite mission Sentinel 1, which provides free data, InSAR techniques could involve less financial resources than the other methods.

Best results can be obtained by combining different monitoring techniques.

\section{Conclusions}

Urban subsidence induced by groundwater overexploitation continues to be a current problem nowadays. Both in-situ and space techniques are used for monitoring this phenomena. As classic techniquesincluding here precise leveling and extensometry- which suffered different improvements over time, the SAR techniques developed during the last two decades are still in the process of refinement. New SAR processing algorithms and approaches are developed, considering also the great amount of satellite data available today (including free data), compared to the previous decades. With the appearance of more monitoring techniques, the use of combining measurements can provide more land subsidence information, helping in understanding this phenomena, despite the individual limitations of each technique.

This work was supported by a grant of the Romanian National Authority for Scientific Research and Innovation, CCCDIUEFISCDI, project number 48/2013 Cofound-202-INXCES, within PNCDI III. 


\section{References}

1. Allaby, M., A Dictionary of Geology and Earth Sciences (4th ed.). Oxford University Press. (2013).

2. USGS. California Water Science Center. Retrieved from URL: https://ca.water.usgs.gov/land subsiden ce/california-subsidence-cause-effect.html (2017).

3. Galloway, D. L., \& Burbey, T. L., Review: Regional land subsidence accompanying groundwater extraction. Hydrogeology Journal, 19, 1459-1486. doi:10.1007/s10040-011-0775-5 (2011).

4. Poland, J. S., Guidebook to studies of land subsidence due to ground-water withdrawal. UNESCO. (1984).

5. UNESCO. Land Subsidence. Retrieved from Land Subsidence: http://landsubsidenceunesco.org/ content/what-land-subsidence, (2015).

6. Poland, J., Land subsidence stopped by artesianhead recovery, Santa Clara Valley. IAHS/AISH Pub. No. 121, 124-132. (1977).

7. Bitelli, G., Bonsignore, F., Pellegrino, I., \& Vittuari, L., Evolution of the techniques for subsidence monitoring at regional scale: the case of EmiliaRomagna region (Italy). 372, pp. 315-321. Copernicus Publications on behalf of the International Association of Hydrological Sciences. doi:10.5194/piahs-372-315-2015, (2015).

8. Samsonov, S., d'Oreye, N., González, P., Tiampo, K., Ertolahti, L., \& Clague, J., Rapidly accelerating subsidence in the Greater Vancouver region from two decades of ERS-ENVISAT-RADARSAT-2 DInSAR measurements. Remote Sensing of Environment, 143, 180-191. Retrieved from https://doi.org/10.1016/j.rse.2013.12.017 (2014).

9. Castellazzi, P., Martel, R., Garfias-Soliz, J., Calderhead, A., Salas-García, J., Huang, J., \& Rivera, A., Groundwater Deficit And Land Subsidence In Central Mexico Monitored By Grace And Radarsat-2. IEEE Geoscience and Remote Sensing Symposium (pp. 2597-2600). Quebec City: IEEE Xplore. doi:10.1109/IGARSS.2014.6947005, (2014).

10. Solari, L., Ciampalini, A., Raspini, F., Bianchini, S., Zinno, I., Bonano, M., Casagli, N., Combined Use of $C$ - and X-Band SAR Data for Subsidence Monitoring in an Urban Area. Geosciences, 7(21). doi: 10.3390/geosciences7020021, (2017).

11. Raspini, F., Loupasakis, C., Rozos, D., Adam, N., \& Moretti, S., Ground subsidence phenomena in the Delta municipality region (Northern Greece): Geotechnical modeling and validation with Persistent Scatterer Interferometry. International Journal of Applied Earth Observation and Geoinformation, 28, 78-89. (2014).

12. Ruiz-Constan, A., Ruiz-Armenteros, A., LamasFernandez, F., Martos-Rosillo, S., Delgado, J., Bekaert, D., ... . de Galdeano, C. Multi-temporal InSAR evidence of ground subsidence induced Multi-temporal InSAR evidence of ground subsidence induced. Environ Earth Sci, 75(242), 116. doi:10.1007/s12665-015-5051-x, (2016).

13. Bakon, M., Papco, J., Perissin, D., Sousa, J. J., \& Lazecky, M., Multi-sensor InSAR deformation monitoring over urban area of Bratislava (Slovakia). Procedia Computer Science, 100, 1127 1134. doi:10.1016/j.procs.2016.09.265, (2016).

14. Parcharidis, I., Lagios, E., Sakkas, V., Raucoules, D., Feurer, D., Le Mouelic, S., Cooksley, G. Subsidence monitoring within the Athens Basin (Greece) using space radar interferometric techniques. Earth Planets Space, 58, 505-513. (2006).

15. Karila, K., Karjalainen, M., Hyyppä, J., Koskinen, J., Saaranen, V., \& Rouhiainen, P. A Comparison of Precise Leveling and Persistent Scatterer SAR Interferometry for Building Subsidence Rate Measurement. ISPRS Int. J. Geo-Inf., 2, 797-816. doi:10.3390/ijgi2030797, (2013).

16. Hirono, T. Niigata ground subsidence and groundwater change. (L. J. Tison, Ed.) Land subsidence, Internat. Assoc. Sci. Hydrology, 1, 144-161. (1969).

17. Riley, F., Developments in borehole extensometry. (C. L. Johnson AI, Ed.) Land subsidence. Proceedings of the Third International Symposium on Land Subsidence, 169-186. (1984).

18. Zerbini, S., Richter, B., Rocca, F., van Dam, T., \& Matonti, F. A, Combination of Space and Terrestrial Geodetic Techniques to Monitor Land Subsidence: Case Study, the Southeastern Po Plain, Italy. JOURNAL OF GEOPHYSICAL RESEARCH, 112 (B05401). doi:10.1029/2006JB004338, (2007).

19. Armas, I., Gheorghe, M., Lendvai, A., Dumitru, P., Badescu , O., \& Calin , A., InSAR validation based on GNSS measurements in Bucharest. International Journal of Remote Sensing, 37(32), 5565-5580. http://dx.doi.org/10.1080/01431161.2016.1244367 (2016).

20. Bamler, R., \& Hartl, P., Synthetic aperture radar interferometry. Inverse Problems, 14, R1-R54. (1998).

21. Ferretti, A., Monti-Guarnieri, A., Prati, C., Rocca, F., \& Massonnet, D., InSAR Principles: Guidelines for SAR Interferometry Processing and Interpretation (TM-19, February 2007). ESA Publications. (2007).

22. Chelbi, S., Khireddine, A., \& Charles, J. Interferometry process for satellite images SAR. ELECO 20117 th International Conference on Electrical and Electronics Engineering, 1-4 December, (pp. 180-184). Bursa, TURKEY. (2011).

23. Declercq, P.-Y., Gerard, P., Pirard, E., Perissin, D., Walstra, J., \& Devleeschouwer, X., Subsidence related to groundwater pumping for breweries in Merchtem area (Belgium), highlighted by Persistent Scaterrer Interferometry. Int J Appl Earth Obs Geoinformation, 63, 178-185. Retrieved from http://dx.doi.org/10.1016/j.jag.2017.07.012, (2017). 
24. Wasowski, J., \& Bovenga, F., Investigating landslides and unstable slopes with satellite Multi Temporal Interferometry: Current issues and future perspectives. Engineering Geology, 174, 103-138. Retrieved from http://dx.doi.org/10.1016/j.enggeo.2014.03.003, (2014).

25. Tesauro, M., Berardino, P., Lanari, R., Sansosti, E., \& Fornaro, G., Urban subsidence inside the city of Napoli (Italy) observed by satellite radar interferometry. Geophisical Research Letters, 27(13), 1961-1964. (2000).

26. Herrera, G., Fernandez, J., Tomas, R., Cooksley, G., \& Mulas, J., Advanced interpretation of subsidence in Murcia (SE Spain) using A-DInSAR data modelling and validation. Natural Hazards and Earth System Sciences, 9, 647-661. doi:10.5194/nhess-9-647-2009, (2009).

27. Fruneau, B., Deffontaines, B., Rudant, J.-P., Le Parmentier, A.-M., Colesanti, C., Le Mouelic, S., . . . Ferretti, A., Conventional And Ps Differential Sar Interferometry For Monitoring Vertical Deformation Due To Water Pumping: The Haussmann-St-Lazare Case Example (Paris, France). Proceedings of FRINGE 2003 Workshop, 1-5 December 2003. Frascati, Italy: (ESA SP-550. Retrieved from http://earth.esa.int/fringe03/ proceedings/papers/38 fruneau.pdf, (2004).

28. Ferretti, A., Prati, C., \& Rocca, F. Permanent Scatterers in SAR Interferometry. IEEE TRANSACTIONS ON GEOSCIENCE AND REMOTE SENSING, 39(1), 8-20. (2001).

29. Berardino, P., Fornaro, G., \& Lanari, R. A New Algorithm for Surface Deformation Monitoring Based on Small Baseline Differential SAR Interferograms. IEEE TRANSACTIONS ON GEOSCIENCE AND REMOTE SENSING, 40(11), 2375-2383, doi:10.1109/TGRS.2002.803792, (2002).

30. Yan, Y., Doin, M.-P., López-Quiroz, P., Tupin, F., Fruneau, B., Pinel, V., \& Trouvé, E., Mexico City Subsidence Measured by InSAR Time Series: Joint Analysis Using PS and SBAS Approaches. IEEE Journal Of Selected Topics In Applied Earth Observations And Remote Sensing, 5(4), 1312 1326. doi:10.1109/JSTARS.2012.2191146. (2012).

31. Cabral-Cano, E., Dixon, T., Miralles-Wilhelm, F., Díaz-Molina, O., Sánchez-Zamora, O., \& Carande, R., Space geodetic imaging of rapid ground subsidence in Mexico City. GSA Bulletin, 120(11/12), 1556-1566. doi:10.1130/B26001.1, (2008).

32. Auvinet, G., Méndez, E., \& Juárez, M., Recent information on Mexico City subsidence. Proceedings of the 19th International Conference on Soil Mechanics and Geotechnical Engineering. Seoul, (2017).

33. Sato, C., Haga, M., \& Nishino, J., Land Subsidence and Groundwater. International Review for Environmental Strategies, 6(2), 403 - 424
Retrieved from https://pub.iges.or.jp/pub/landsubsidence-and-groundwater-management, (2006).

34. Yamamoto, S., Recent trend of land subsidence in Japan. IAHS/AISH Pub, No 121, p. 9-15, (1977).

35. Shimizu, Ryosaku, Land subsidence in Japan. Booklet prepared for International Symposium (1969)

36. Erkens, G., Bucx, T., Dam, R., de Lange, G., \& Lambert, J. Sinking coastal cities. Proc. IAHS. 372, pp. 189-198. Copernicus Publications on behalf of the International Association of Hydrological Sciences. doi:10.5194/piahs-372-189-2015, (2015).

37. Rokugawa, S., \& Nakamura, T., Long-range ground deformation monitoring by InSAR analysis. Proc. IAHS. 372, pp. 343-346. Copernicus Publications on behalf of the International Association of Hydrological Sciences. doi:10.5194/piahs-372-3432015, (2015).

38. USGS, Texas Gulf Coast Groundwater and Land Subsidence: Over forty years of Research in the Houston-Galveston Region, https://txpub.usgs.gov/ houston_subsidence/home/ (2018)

39. Qu, F., Lu, Z., Zhang, Q., Bawden, G. W., Kim, J.W., Zhao, C., \& Qu, W., Mapping ground deformation over Houston-Galveston, Texas using multi-temporal InSAR. Remote Sensing of Environment, 169, 290-306. Retrieved from http://dx.doi.org/10.1016/j.rse.2015.08.027, (2015).

40. Bawden, G., Johnson, M., Kasmarek, M., Brandt, J., \& Middleton, C, Investigation of Land Subsidence in the Houston-Galveston Region of Texas by using Global Positioning System and Interferometric Synthetic Aperture Radar,19932000, Scientific Investigations Report 2012-5211, U.S. Geological Survey, (2012).

41. Ivan, I.M., Popa, I., Up-to-date hydrodynamic and hydrochemical state of the Fratesti deep aquifer system in the Bucharest area, Transactions on Hydrotechnics, 57(71), Fascicola 1, (2012).

42. Vîjdea, A. \& Bindea, G.,. D7.1.33 GeoHazard Description for Bucharest, Enabling Access to Geological Information in Support of GMES (PANGEO) http://www.pangeoproject.eu,(2013)

43. CCIAS, Integrated service for urban subsidence phenomena based on space-borne interferometric synthetic aperture radar (InSAR) and hydrogeological-geotechnical hybrid modeling "SIRYS"- Final Summary Report, (2015).

44. Armaş, I., Mendes, D., Popa, R-G., Gheorghe, M., Popovici, D., Long-term ground deformation patterns of Bucharest using multi-temporal InSAR and multivariate dynamic analyses: a possible transpressional system?, Nature, 7(43762), (2017). 